\title{
COMMENTS
}

\section{Interventions in reproduction}

\author{
D S SHERIFF', S OMER SHERIFF ${ }^{2}$
}

'Jubilee Mission Medical College and Research Institute, Thrissur, 680005 INDIA e-mail: drdsheriff@eth.net ${ }^{2}$ Ragas Dental College, Chennai 600119 INDIA

\begin{abstract}
Assisted reproductive technology has helped many childless couples. It has also raised questions about how appropriate the technology might be in different situations. How we understand parenthood is crucial in taking a stand on such scientific intervention. It is suggested that physicians should decide on offering artificial insemination, surrogacy and in-vitro fertilisation only after considering if the child will have good parents and if there will be legal complications from the use of the technology.
\end{abstract}

Infertility is defined as the failure to conceive after one year of unprotected sexual intercourse. This can be due to a male factor, a female factor, a combination of the two, or it may be unexplained infertility. Solutions such as artificial insemination are by now old technology, but in-vitro fertilisation (IVF) is relatively new. The first documented "test tube" baby was born in India in Mumbai in 1986 (1). A number of related technologies have since been developed.

A key question often asked about these technologies is: Does such scientific intervention enhance or debase the meaning of parenthood? Is becoming a parent ethical only within the framework of a stable and loving union between a husband and wife?

Some argue that procreation is moral only between a husband and wife who are able to impregnate and conceive in the natural way (2). If the couple is unable to have children naturally, they have no moral right to request intervention. They must maintain their integrity as a married couple and preserve their marital union from adulterous intrusion and the difficulties created by insemination of donor sperm such as questionable genealogy, legitimacy and the possibility of incest. Both Roman Catholicism (3) and Orthodox Judaism (4) take this stand.

\section{Artificial insemination by donor}

Some religious beliefs regard artificial insemination by donor (AID) as immoral because it is depersonalising. Even artificial insemination with the husband's semen is considered immoral. Sexual impotence and sterility following cancer therapy do not modify the Catholic proscription against artificial insemination with either a donor's or the husband's sperm. In this view, artificial insemination makes marriage "nothing more than a biological laboratory" whereas the marriage union by its very nature requires the personal activity of both partners (5). Jewish teaching permits the use of the husband's sperm for artificial insemination provided certain conditions are met (3). The teaching, however, is not uniform regarding the method used to obtain the sperm (4).
Such prohibitions are based on the argument that marriage is an intensely personal union, an exclusive covenant, and that only within its confines is it moral to use one's life-giving potential.But can this be a moral imperative? Marriage should also ideally last "till death" but the church and most of the eastern philosophies now tolerate divorce $(6,7)$.

AID could be treated as adultery, but the prohibition against adulterous physical intercourse is related to inheritance. The notion of sexual exclusivity was linked to the idea of ownership: wives were property. This argument does not apply in AID. The husband knows that he is not the biological father and he is willing to become a parent.

The anonymity of the donors can work against the interests of the child who, at present, is not entitled to find out her/his genetic makeup or biologic roots. Even adopted children, except in certain jurisdictions, cannot find out anything about either birth parent and this is reportedly causing problems (3). But no one is arguing against adoption for that reason. In AID, then, much depends on the discretion of the physician in screening possible donors (7).

AID may be regarded as ethical because it enhances the lives of couples who cannot conceive. However, a lot depends on each physician's discretion and experience of dealing with childlessness. Should a single woman be inseminated? A woman living with a man without any matrimonial bond? Women in homosexual relationships? I believe that if the doctor is not convinced that the best interests of the (potential) child will be served - regardless of whether the patient is single or married - it is her or his obligation to not cooperate. This can only be done when the doctor does not impose her/his values on the patient.

\section{Surrogate motherhood}

Some consider surrogacy to be the female counterpart of AID. Technically, the physician who artificially inseminates a surrogate mother with sperm from the male partner of an infertile woman is performing the same procedure as inseminating a woman with donor sperm when her husband is infertile. Many of the objections are the same - the psychological state of a sterile spouse or one who is at genetic or medical risk, the subsequent impact of this procedure on the couple, the selection of the surrogate parent.

Surrogate motherhood has ethical issues related to AID, but with some important differences. The woman who is impregnated 
is more involved than the anonymous sperm donor used for artificial insemination. The sperm donor is not anonymous for surrogate motherhood.

Surrogacy or host stand-in motherhood may turn into pregnancy for profit (or "womb rent"), which raises important legal questions. But I suggest that the motivation of the surrogate mother does not make a childless couple's desire to have a baby unethical. The motivation of a physician or lawyer who engages the services of a surrogate mother must also not impinge upon the moral position of an infertile couple who are considering this procedure.

A major objection to surrogate motherhood remains a fundamental one -- that procreation is separated from the physical expression of love (coitus) and from the nurturing during pregnancy. How we understand the nature of parenthood is crucial in taking a moral stand on such scientific intervention.

The primary objection to surrogate motherhood is the absence of a legal framework to address its many dimensions. The status of the child as well as of the others involved is at risk until the rights and responsibilities of all parties are legally defined and enforced. What will happen if the surrogate mother wants to keep the baby? Can she be enjoined from doing so by the overriding legal right of the biological father who has contracted with her? Can the father successfully sue her if she absconds with the baby? If she miscarries, is the payment to be prorated? If the father/husband and his wife get divorced or separate, who will be awarded custody of the child? Are they both free to change their minds in that event? What if either becomes widowed? What if the child is less than perfect? Can a biological father (and his wife if she is a coequal party to the contract) require or prevent an amniocentesis? What if abortion is morally repugnant to the surrogate? If the expectant mother contracts a serious disease or gets a job offer, can she invoke her constitutional right to privacy (to abort)? May she do so despite an existing agreement? Who is responsible if the baby survives an abortion attempt? These are some of the questions that await legal answers.

The conscientious physician, if he or she is not to be regarded as a mere technician, must be satisfied that these safeguards are in effect before cooperating in the conception of a child in a situation of surrogacy.

\section{In-vitro fertilisation}

A central concern of IVF relates to the uncertainty of when human-hood begins and the ethical concerns of discarding a fertilised ovum. For many of the other concerns, the arguments are the same as in AID and surrogate motherhood. However, IVF does occasion more possibilities for, and hence more objections to, the pre-packaging or prefabrication of babies. Some accept IVF only when it is the wife's ovum and the sperm is her husband's, and subsequent implantation is within the wife's uterus; others would accept donor sperm or donor ova.

Other scenarios are not unimaginable: in-vitro fertilisation of donor ova by donor sperm and subsequent implantation in a different woman for ultimate delivery to another couple. The legal quagmire that this could create, as in surrogate motherhood, must be addressed. Another pressing concern is the priority that in-vitro fertilisation should be given when competing advances in medicine will benefit more people.

But who could tell a child born of any of these technologies that they should never have been brought into existence? Ethics probes what is right in an effort to refine our appreciation of human values, the most basic of which is reverence for life.

\section{References}

1. Heikkila K, Lansimies E, Hippelainen M, Heinonen S. A survey of the attitudes of infertile and parous women towards the availability of assisted reproductive technology. BJOG 2004; 111:1229-35.

2. Schaffer P. How babies and families are made. Tabor Sarah Books:Berkeley; 1988.

3. Pope Pius XII. An address to the Italian Catholic-Union of Midwives, October 29, 1951. Catholic Mind 1952:50:61.

4. Rosner F. Test tube babies, host mothers and genetic engineering in Judaism. Tradition 1981; Summer: 142.

5. Nor SNM. New reproductive biotechnology, values and society. EJAIB 1999; 9:166-169.

6. Crawley F. Culture and community in bioethics: the case for an international education programme. In: Fujiki N, Macer D, editors. Bioethics in Asia: proceedings of the UNESCO Asian Bioethics Conference 1997 Nov 3-8; Kobe/Fukui, Japan. Eubios Ethics Institute; 1998. p 136-9.

7. Daniels K. Building a family with the assistance of donor insemination. Dunmore Press: New Zealand; 2004. 